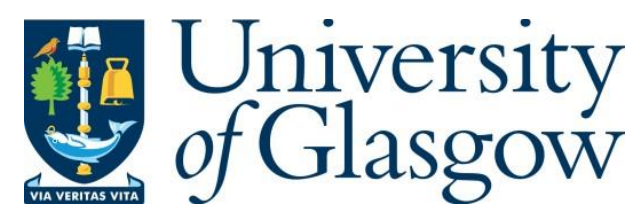

Van Puyvelde, D. (2016) Fusing drug enforcement: a study of the El Paso Intelligence Center. Intelligence and National Security, 31(6), pp. 888-902.

There may be differences between this version and the published version. You are advised to consult the publisher's version if you wish to cite from it.

$\underline{\text { http://eprints.gla.ac.uk/144456/ }}$

Deposited on: 25 July 2017

Enlighten - Research publications by members of the University of Glasgow http://eprints.gla.ac.uk 


\title{
Fusing Drug Enforcement: \\ A Study of the EI Paso Intelligence Center
}

\author{
DAMIEN VAN PUYVELDE
}

\begin{abstract}
This article examines the evolution of the El Paso Intelligence Center (EPIC), a key intelligence component of the Drug Enforcement Administration, to shed light on fusion efforts in drug enforcement. Since 1974, EPIC has strived to fuse the resources and capabilities of multiple government agencies to counter drug trafficking and related threats along the Southwest US border. While undergoing a steady growth, the Center has confronted a host of challenges that illuminate the uses and limits of multi-agency endeavors in drug enforcement. An evaluative study of the Center shows that it is well aligned with the federal government priorities in the realm of drug enforcement; however the extent to which the Center's activities support the government's efforts in this domain is not so clear. The Center needs to improve the way it reviews its own performance to better adapt and serve its customers.
\end{abstract}

\section{Fusion centers: more than a trend}

In the last decade, there has been much public discussion about the role fusion centers can play in support of national security efforts. ${ }^{1}$ This emphasis is related to the $9 / 11$ attacks and the subsequent advent of the global war on terrorism. Following these attacks, number of experts highlighted the failure of key US intelligence agencies, namely the Federal Bureau of Investigation (FBI) and the Central Intelligence Agency (CIA), to share intelligence in their effort to maintain national security. ${ }^{2}$ Acknowledging this shortcoming, the federal government launched a series of initiatives, including the establishment of a new "information sharing environment" under the auspices of the Office of the Director of National Intelligence (ODNI), and the creation by the Department of Homeland Security (DHS) of a nationwide system of 78 fusion centers 
supposed to enable information and intelligence sharing between local, tribal, state, and federal agencies. ${ }^{3}$

Fusion centers have been one of the key instruments used by the US government to adopt a more networked approach to national security. ${ }^{4}$ The coordination they foster is believed to be essential to tackle the threats posed by transnational criminal and terrorist organizations, which seek to benefit from the jurisdictions and boundaries that limit government authorities. ${ }^{5}$ Fusion centers bring together representatives from a variety of agencies together and act as "a mechanism to exchange information and intelligence, maximize resources, streamline operations and improve the ability" to "detect, prevent, investigate and respond to" security threats. ${ }^{6}$ Over the long term, their establishment is expected to have a cultural effect, instilling a common ethos among participating members. Given the important role entrusted to fusion centers and the significant public resources invested in them, assessing their ability to achieve these short and long term goals is an important task. ${ }^{7}$

Recent academic discussions on intelligence fusion have often focused on counterterrorism. ${ }^{8}$ Considering the US government's efforts to better integrate counterterrorism since the 9/11 attacks, this is understandable. However, the fusion of resources and capabilities has long been used, formally and informally, to support a host of security efforts in the United States and elsewhere. ${ }^{9}$ In the United States, the roots of modern fusion centers can be traced to the law enforcement community where fusion has long been used as a part of temporary task forces and more permanent intelligence centers. ${ }^{10}$ This article seeks to fill a gap in the literature about the role of multi-agency efforts in the context of drug enforcement, by examining the evolution of the El Paso Intelligence Center (EPIC), one of the main intelligence components of the Drug Enforcement Administration (DEA), and evaluating its performance. ${ }^{11}$

EPIC was established in 1974 and, according to the DEA, it was "the first major attempt at a permanent interagency operation in law enforcement." 12 By fusing the resources and expertise of its members, analyzing data and disseminating crime intelligence to law enforcement officers, ${ }^{13}$ EPIC aims to offer the strategic, operational and tactical resources necessary to strengthen the government's effort to interdict narcotics and weapons trafficking, as well as alien smuggling, along the Southwest 
border. A DHS official goes as far as to credit EPIC as an inspiration behind the multiplication of fusion centers in the early twenty-first century. ${ }^{14}$ If the origins of fusion in the US lie in drug enforcement, EPIC is a particularly relevant case to study, not only because of its 40 years history, but also because of its location at the heart of the government's counternarcotic efforts. ${ }^{15}$

An overview of the evolving scope of activities of the Center provides the context for considering EPIC's performance. The limited literature on EPIC has mostly been written in professional magazines by staff, and unsurprisingly tends to emphasize EPIC's tactical successes, or its ability to turn "raw data into actionable intelligence" leading to arrests and drug seizures. ${ }^{16}$ Much of this literature uses specific examples to present the Center as a successful organization able to coordinate the intelligence collection and analytical capabilities of a variety of government agencies to locate and apprehend criminals. ${ }^{17}$ These success stories are informative but they do not provide a systematic assessment of EPIC's activities based on the Center's mission.

To assess the performance of the El Paso Intelligence Center, this article focuses on three main components - processes, enablers and outcomes - and examines the extent to which they are aligned with EPIC's main goal: supporting drug enforcement efforts along the Southwest border. ${ }^{18}$ The core processes implemented at EPIC broadly follow the intelligence cycle and include tasking, collection, analysis and production, and dissemination and feedback. The article examines how EPIC approaches each of these steps and identifies related shortfalls, including a lengthy intelligence production process, and the limited gathering of feedback from its customers. A number of resources and capabilities make EPIC's core processes possible and, in the best cases, effective. These enablers include governance, information communication technology, and human resources. ${ }^{19}$ Each of these enablers poses recurring challenges that require continued attention by the Center's leadership. Progress in the domain of human resources, in particular, including the systematic gathering of feedback from EPIC's own staff and the provision of common training programs, could reinforce the interagency ethos of the Center and suggest ways to produce intelligence in a more timely manner.

The Center's activities serve a series of outcomes that are aligned with some of the federal government's strategic goals in the realm of drug enforcement. The 
achievement of these outcomes is typically measured thanks to a series of outputs, or concrete services and products offered by EPIC to support law enforcement efforts. ${ }^{20}$ However, the Center's performance reviews have been limited by the absence of systematic mechanism to gather feedback from its customers and employees. Recent progress in this area is notable, but it will need to be followed upon by a methodical effort to gather and exploit feedback. This will pave the way for more comprehensive and continuous assessments of EPIC's ability to support drug enforcement, and should in turn allow the Center to adapt and better serve its customers.

\section{The Origins of EPIC}

In the early 1970s much of the focus of the federal government was directed towards a global war on the manufacture, distribution and use of narcotics. ${ }^{21}$ Congress passed the Controlled Substances Act in 1970, and three years later President Richard Nixon signed a presidential reorganization plan that merged pre-existing organizations - the Bureau of Narcotics and Dangerous Drugs, the Office for Drug Abuse Law Enforcement and the Office of National Narcotics Intelligence (ONNI) - into a single agency, the DEA. ${ }^{22}$ This consolidation of drug law enforcement sought to provide momentum in the war on drugs, coordinate the government's drug enforcement efforts across local, state, national and international levels, and make drug enforcement more accountable. ${ }^{23}$

The newly-created DEA established its Office of Intelligence on July 1, 1973, thus affirming the importance of intelligence in the fight against criminal networks. From its onset, DEA intelligence was marked by the law enforcement culture. DEA's job is to put criminals in jail, and as a result, the intelligence it develops is primarily investigative and tactical. When information is gathered, it is expected to lead to arrests and seizures. DEA intelligence has traditionally been produced to serve two main types of consumers: senior decision-makers like the DEA administrator and other federal, state and local

agencies. ${ }^{24}$ As a result, the agency's intelligence capability was initially divided into an Office of Intelligence located at the headquarters and regional intelligence units. At the regional and local levels, the use of multi-agency task forces allowed law enforcement officers to overcome cross-jurisdictional challenges and strengthen DEA's enforcement 
missions. At the federal level, DEA intelligence informed the strategies and plans developed by senior decision-makers.

The Unified Intelligence Division, established in 1973, was the first DEA field intelligence unit based on the concept of task force. This division brought together DEA special agents, DEA intelligence analysts, New York State Police investigators and New York City detectives who systematically engaged all aspects of the intelligence process in the context of law enforcement intelligence. ${ }^{25}$ That same year the DEA launched its first federal law enforcement automated index, a record management system called the National Narcotics Intelligence System. Some of the defining features of law enforcement intelligence appear very clearly in this early history of DEA intelligence, including the importance given to supporting intelligence consumers at various levels of government, and the use of databases and task forces to support decisions at the tactical level.

The border between the United States and Mexico was and remains a longstanding challenge for the US government and its law enforcement community. Boundaries create jurisdictional limits, which criminals seek to use to their advantage. Illicit drugs, undocumented aliens and contrabands, as well as cash and weapons have been smuggled across the Southwest border for decades, and it is somewhat naturally that the federal government paid particular attention to this region as a part of its more general reform of drug enforcement in the 1970s. ${ }^{26}$ Border intelligence has traditionally been composed of several systems directed towards specific enforcement targets. A Bureau of Narcotics and Dangerous Drugs report found in 1973 that the DEA, the Customs Services, the Federal Bureau of Investigation (FBI), the Federal Aviation Authority (FAA), the Immigration and Naturalization Service (I\&NS) and the Bureau of Narcotics and Dangerous Drugs itself were all collecting raw intelligence on drug, the smuggling of weapons and aliens along the Southwest border, but were not coordinating and analyzing trends in any systematic way. ${ }^{27}$

Taking act of this situation, a Department of Justice (DOJ) report recommended establishing a Southwest Border Intelligence Service Center to "provide for the most effective sharing of intelligence developed by border enforcement agencies." ${ }^{28}$ The center would: 
consolidate, analyze, and disseminate on request all-source data regarding border related violations; identify conspirators and the scope and method of their activities; assess and evaluate border conspiracy operations; and develop and maintain coordination with the Southwest border enforcement agencies so that a prompt response can be mounted for "hot" intelligence items developed by one agency that fall under the responsibility of another. $^{29}$

The DOJ further recommended the DEA be in charge of the center, which would be staffed jointly by representatives of the DEA, I\&NS and Customs. Considering the broader role of intelligence in law enforcement, the report imagined a center that would primarily support field agents on a 24-hour basis, "facilitate information exchange between Washington and the field," and host "data terminals capable of accessing participating agency data bases." 30

These recommendations were acted upon and the DOJ established the El Paso Intelligence Center in 1974. The city of El Paso, TX, located at the midpoint of the USMexican border, and bordering the state of New Mexico, appeared as a logical place to set up a center aiming to facilitate drug enforcement coordination at the local, state, federal and international levels. ${ }^{31}$ The Center quickly expanded to form a "prototype" of national narcotics intelligence system serving "federal, state and local law enforcement agencies with data from various sources. ${ }^{~} 32$ EPIC effectively acted as a clearinghouse for drug related information, in particular information about drug movement in land, air, sea, alien smuggling, and weapons trafficking. This information was stored in manual databases and used to support interdiction efforts. ${ }^{33}$ For example, EPIC stored information received from DEA pilots who identified suspect vessels in Colombia thanks to reconnaissance flights, crosschecked the information and relayed it to the US Coast Guards who were able to stop these vessels. ${ }^{34}$

\section{A Steady Growth}


From its initial focus on the Southwest border, EPIC's scope has grown to include worldwide drug smuggling and other criminal activities with a particular concentration on the Western hemisphere. ${ }^{35}$ One rationale behind this expansion is that nearly all the contraband and criminal activities along the Southwest border have substantial connections to locations that are more remote. The scope of activities of the DEA and EPIC further expanded as a result of the increasing globalization of drug trafficking in the last decades. ${ }^{36}$

EPIC's functions and capabilities have expanded in parallel. Seventeen employees initially staffed the Center in 1974. This workforce grew up to 100 employees in the 1980s, 300 in the 1990s, and over 400 today. ${ }^{37}$ The number of agencies contributing to the Center also multiplied from three federal agencies to 28 federal, state, and local agencies, and four foreign liaison officers from the Mexican military, justice and police, and the Colombian national police. ${ }^{38}$ Today, the Center has agreements to share information and intelligence with all 50 US states, Guam, Puerto Rico, the Virgin Islands and the District of Columbia. Memoranda of understanding have been signed with Canada, Australia, and the Netherlands and law enforcement agencies in these countries are, in principle, able to consume and share information with EPIC. In practice, international cooperation remains limited, and foreign partners are generally not granted direct access to the databases and finished intelligence products available to EPIC's American customers. ${ }^{39}$

The demand for EPIC's products and services has grown over the years. From a few hundreds of customers in the mid-1970s, EPIC reported more than 19,000 approved users in 2009, a quarter of which were from the DEA, less than a quarter from other federal agencies, and 55 percent from state and local police and sheriff departments. The latter have become increasingly important consumers of EPIC's products and services in the last few years. ${ }^{40}$ The total number of requests for information (RFI) operated by the Center also increased "from 16,745 in 1975 to over 196,000 in fiscal year 1981." ${ }^{41}$ In 2011, the Center answered 333,000 RFI, supported 18,000 cases and produced 6,000 reports. ${ }^{42}$ By comparison, from 1 August 2012 through 31 July 2013, the DHS-led National Network of Fusion Centers responded to 228,892 RFIs from agencies within fusion center areas of responsibility. ${ }^{43}$ Even though the methodologies to count these RFI 
may vary, this comparison confirms that EPIC's services are in relatively high-demand. According to the Department of Justice, "intelligence contributions, database queries, system users, and on-board staffing commitments from partner agencies" at EPIC all increased from 2001 to 2012. ${ }^{44}$ The apparent growth of EPIC presents the Center as a successful organization able to attract support, expand its scope of activities and its customer base.

In recent years, support for EPIC was reinforced by at least two factors: the terrorist threat to the US and drug trafficking-related violence in Mexico. In the aftermath of the 9/11 attacks, the US government operated a rapprochement between the intelligence and law enforcement communities based on the nexus between crime and terrorism. ${ }^{45}$ This possibility led the US government to reintegrate the DEA's Office of National Security Intelligence and its vast networks of informants within the intelligence community. ${ }^{46}$ From this perspective, drug activity could provide both the financial means and transit mechanism for terrorists and their weapons to reach the US homeland. The possibility that terrorists illegally cross the US-Mexico border led to a focus on counterterrorism along the border, which inevitably became tied to the long-standing issues of drug trafficking and illegal immigration. It is important to note that the crimeterror nexus is not a theoretical construct created to attract more federal funding towards law enforcement agencies but a reality that ought to be considered seriously. In one notable case, a narcotics investigation on a Canadian organization that provided precursor chemicals to a Mexican drug ring, revealed the trafficking organization to be a Hezbollah support cell. $^{47}$

To support counterterrorism, law enforcement agencies have been encouraged to turn toward intelligence-led policing and develop an increasingly collaborative analytical environment in which all-source fusion is the norm. ${ }^{48}$ The mission of the DEA has thus expanded to support homeland security efforts, and EPIC, according to one of its former deputy directors, was turned into an "all-threat center." 49 Fusion centers, like EPIC, have provided the necessary structure to integrate and coordinate various agencies' capabilities and fight the crime-terror nexus. They provide an ideal platform to harness connections between the federal, state, local, and tribal elements of the national security enterprise. ${ }^{50}$ This capability is particularly useful in the struggle against terrorism, because terrorist 
organizations, much like drug trafficking organizations, need to plan their activities to be successful, and when doing so they are likely to draw the attention of local authorities.

According to the DEA, EPIC was called upon to support investigations to find those responsible for the $9 / 11$ attacks because of its experience in supporting drug interdiction and investigations regarding criminal activities. ${ }^{51}$ The Center was also used to check the names of four suspects involved in the 2005 London subway bombings. EPIC's information reportedly allowed investigators to draw a number of connections that helped identify more than a dozen individuals with international terrorist connections in the US. ${ }^{52}$ These stories suggest that EPIC can provide useful to support counterterrorist efforts. However, as long as EPIC belongs to the DEA, its efforts to counter terrorism are likely to remain secondary to its drug enforcement mission.

The Center remains to this day a key component of the government counternarcotic strategies, which emphasize its role in the promotion of intelligence and information sharing. ${ }^{53}$ Support for law enforcement efforts along the Southwest border, including EPIC, was reinforced in the mid-2000s when cartel violence soared in Mexico and threatened to affect US interests and security along the border. ${ }^{54}$ The 2010 slayings at the US Consulate in Ciudad Juarez, a Mexican city that lies just south of El Paso, raised much concern and lead the government to augment law enforcement capabilities in El Paso and provide greater support to the Mexican security apparatus.

Since EPIC is well aligned with federal strategies, the Center received significant financial support to expand its facilities and improve its information systems in the last few years. ${ }^{55}$ EPIC has clearly been successful at garnering support from key decisionmakers in the executive and legislative branches of government and this allowed the Center to grow. However, assessing EPIC's performance requires a deeper examination of the Center's inner working.

\section{Processes, services and products}

EPIC's core mission has not changed much since its origins. According to the DOJ, the Center supports US "law enforcement and interdiction components through timely analysis and dissemination of intelligence on illicit drug and alien movements and the 
criminal organizations responsible for these illegal activities." 56 EPIC's processes, services and products are designed to fulfill this mission.

EPIC's production process typically starts with a RFI that originates from outside of EPIC and is communicated by phone, email or through an online platform. The Center gives free access to millions of records, but direct access is limited to federal and state agencies primarily to limit the number of queries. This does not preclude sheriff offices and police departments' to gain access to the information stored at EPIC; federal and state agencies can run queries on behalf of them, and exceptions are made when there is a special need, for example if an office is frequently involved in highway drug interdiction activity. All queries made to the Center are received, executed and responded by human operators; this system aims to provide better service to EPIC's customers but it also hinders the volume of queries that can be dealt with. ${ }^{57}$

The requests made to EPIC vary widely. Some of them simply require a database check on a vehicle plate number; others necessitate an assessment by subject matter experts. These requests are normally transmitted to the Joint Collection Management Unit (JCMU), which prioritizes requirements and dispatches them across the various units and teams composing the Center. ${ }^{58}$ In practice, requests are sometimes communicated directly to a specific subject matter expert manning one of EPIC's units, without going through the JCMU. The employees receiving such direct requests need the approval of their supervisor to start working on them.

One of the key tasks of EPIC is to provide real-time tactical support, helping law enforcement officers to track and target drug traffickers. ${ }^{59}$ The watch operations section, a one-stop shop that gives law enforcement and national security officials access to multiple confederated databases at one time, is an essential part of EPIC's efforts at this level. This 24-hour, seven-days-a-week operations center responds to inquiries from government authorities regarding suspect individuals, vehicles, vessels, aircrafts, documents etc. The watch also sends lookouts for persons, vehicles, vessels, aircrafts and other alerts when requested by law enforcement agencies. Essentially, this section turns raw data into information and facilitates its dissemination to support law enforcement and interdiction in the field. ${ }^{60}$ The core mission of the watch is three-pronged: enabling officers to make better-informed judgments, protecting their safety, and increasing the 
likelihood of their tactical success. Watch personnel rely on more than 70 federal, state and local databases to provide information in a timely manner (ideally under 30 minutes) to the requesters, usually law enforcement officers in tactical situations. ${ }^{61}$

To ensure broader and more comprehensive access to its databases EPIC launched the open connectivity project in 2006 . This portal provides users with web-based and direct access to EPIC data covering more than 35 years of activities related to drugtrafficking and collected from state and local agencies. In recent years, EPIC has been able to provide a reply to a majority of the requests made to its federated database systems. From 2005 to 2014, 59 percent of the requests made to this system were matched by existing data in one of the databases queried by EPIC employees. ${ }^{62}$ An important resource available through this system is the National Seizure System (NSS), an EPIC database that tabulates information about drug seizures throughout the world with a particular focus on the US. In 2010, the DOJ Inspector General (IG) found that, as a result of the lack of standard procedure, the data contained in the NSS was inaccurate and incomplete. ${ }^{63}$ Five years later, EPIC finally hired technicians who started cleaning up this system to increase its reliability. This is important because the Center's ability to match requests made to its databases is meaningless if the latter are unreliable.

Assessing the Center's performance at the tactical level is complicated because the Center does not systematically gather data on the use that is made of the information it provides to its customers. Outside of major cases leading to important arrests and seizures, EPIC staff receives very little feedback from law enforcement officers in the field. In practice, information provided by the Center may be useful to line officers in a variety of ways without directly leading to arrests and seizures, for example by informing an investigation. In other cases, inaccurate data entries can misinform law enforcement officers and lead to unwanted outcomes. In one case, the spouses were arrested shortly after landing their private plane, which had mistakenly been reported as stolen because of an error in an EPIC database. The ownership of the plane was eventually clarified and the two Americans were released. ${ }^{64}$ Similarly unreliable data could very well lead to suspect aircrafts not being controlled, and to the production of inaccurate reports.

EPIC is more than a clearinghouse for other agencies' information; it is actively involved in the production of intelligence. To respond to the requests they are tasked 
with, EPIC's experts have direct access to all the databases hosted by the Center, and can also use the information collected by their respective agency and EPIC.$^{65}$ EPIC has a limited collection program that includes surveillance capabilities but, for the most part, it relies on participating agencies to collect raw intelligence from all types of sources including confidential informants, signal and geospatial intelligence. ${ }^{66}$ The Center produces a host of periodic reports as well as special publications. These include tactical reports on drug movement, operational assessments of drug trafficking organizations, and strategic assessments of drug-related currency movement, for example. ${ }^{67}$

These core analytical functions and capabilities have not changed much over the last four decades, if anything they have expanded to adapt to the threat environment. EPIC's staff now examines a broader array of threats including terrorism. Given the complexity of the threat environment in which it operates, and the vast amounts of information it processes, the Center has struggled to analyze all the information from the unique sources it possesses. This information overload is problematic to the extent that it has impacted on the quality of EPIC's services and products, which are not always up to date. $^{68}$

EPIC's multi-agency nature and its ability to process and analyze all-source intelligence from a variety of agencies - in a way a single agency could not - add value to its services and products. However, this multi-agency setting also complicates the production of intelligence. Once an analyst has drafted a report, it is sent for peer-review to his or her colleagues working within the same unit, and will then need to be approved by EPIC's hierarchy before it can be disseminated to external consumers (see figure 1). This review process involves the analyst's immediate superior, typically a chief of unit, his or her section chief, then all the section chiefs, the production unit (reviewing language and form), and the executive office (composed of senior officials representing each of the agencies contributing to the Center, the general counsel, the chief of staff, and the director of the Center). At each level, the draft report can be sent back to the analyst for review and will then need to be re-submitted (see dotted arrows and feedback loop in figure 1). 


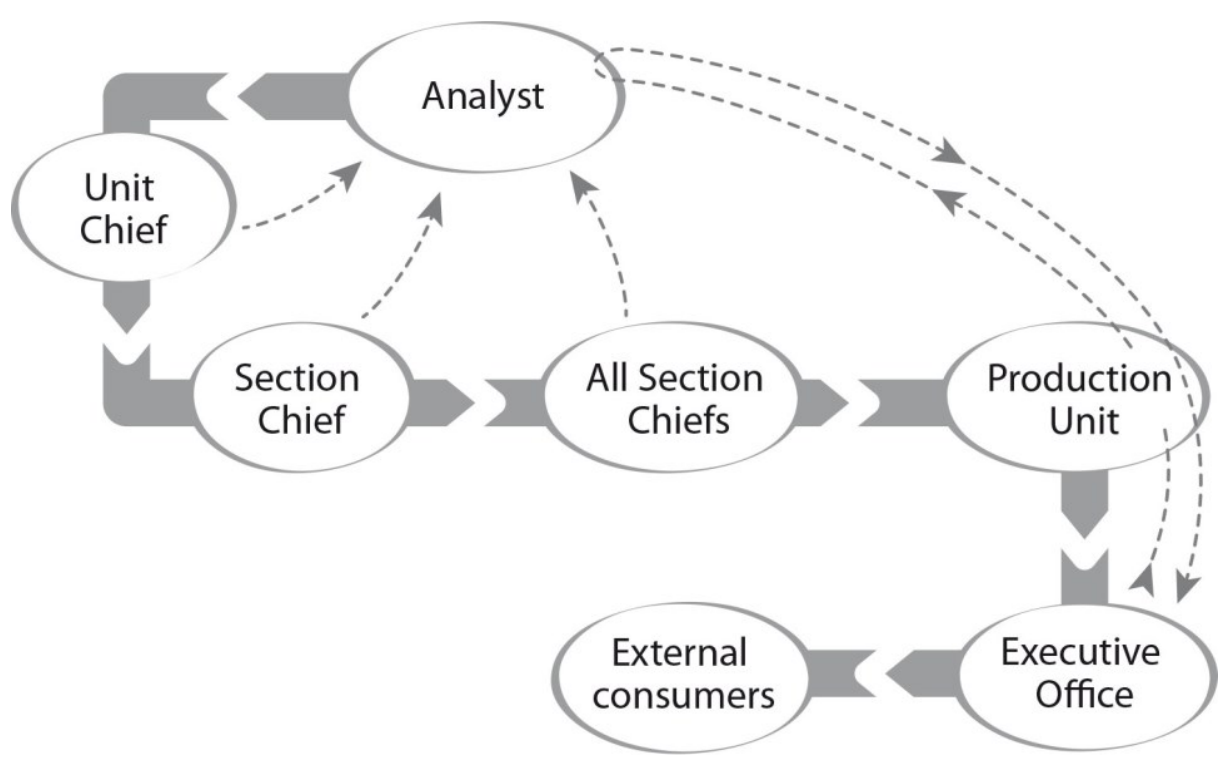

Figure 1 - EPIC's Analytical Review Process

Disagreements on the content of analytical reports often occur at the level of the executive office, where senior officials typically stand for their respective agency's interest, and disregard each other's comments. On the whole, this review process is essential to the making of multi-agency intelligence products, but it slows the production of reports and can significantly decrease their timeliness. This is problematic to the extent that one of EPIC's missions is to provide timely analysis on emerging and current issues and threats to its customers. Depending on the type of product, EPIC's intelligence is disseminated to specific consumers or sent out to vast networks of government employees through distribution lists.

In 2010, a survey of EPIC's customers conducted by the DOJ IG found that a vast majority of them reported high satisfaction with the Center's services and products. According to the study, "most federal, state, and local personnel who responded stated that they viewed EPIC products and services as fully meeting their criteria for timeliness (76 percent), accuracy ( 82 percent), relevance ( 80 percent), and immediate usability (74 percent). ${ }^{, 69}$ Nevertheless, the IG report criticized EPIC for lacking a strategy to publicize and promote its products, and not systematically seeking feedback from its customers. ${ }^{70}$ Five years later (in early 2015), EPIC finally started to include feedback sheets to its intelligence reports. At this stage, it is not clear how the Center's leadership will make use of this new and important resource, and how analysts will benefit from it. 


\section{Enablers}

The processing of information and the production of intelligence at EPIC is made possible thanks to a series of supporting factors including governance, information technology systems and human resources. Patrick Walsh emphasizes the key role these factors play in effective intelligence frameworks, and in particular the importance of a sound governance structure that creates the conditions for effective actions. ${ }^{71}$ In the present case, to be sound, EPIC's governance structure should set the conditions for the effective coordination of drug enforcement resources along the Southwest border.

The Center's governance structure reflects its-multi-agency nature. EPIC is a component of the DEA's Office of National Security Intelligence, which aims to facilitate intelligence coordination and information sharing between the DEA, the IC and the broader US security apparatus. EPIC's director, a DEA senior executive, is supported by a deputy director and four associate deputy directors (ADDs) who represent some of the principal members of EPIC like DHS and the FBI. ADDs and senior representatives of each of the main agencies participating to the Center (called program coordinators) form the executive office. Below the executive office, the Center is currently divided into four sections (support, tactical, operational, strategic), each of which is headed by an ADD. Each section contains number of units and teams, which are typically staffed by subject matter experts from different agencies. This governance structure and the procedures followed to reach multi-agency decisions are defined by EPIC's charter, a document that has been rewritten half a dozen times since EPIC's establishment.

Interagency coordination is the most important governance challenge faced by EPIC because it directly impacts on the Center's ability to fuse multiple agencies' resources and capabilities to serve its customers. Coordination issues are common in the US security apparatus, particularly in multi-agency centers where the law enforcement, intelligence and military communities interact on a daily basis. Differences in organizational culture, procedures, objectives, resources and logistics, all complicate the coordination of various agencies' efforts, even when the latter share similar missions. According to Robert Taylor and Amanda Russell, fusion is particularly challenging for 
law enforcement agencies because they possess a number of traits including their autonomy, organizational ego, and a desire to keep control over their information that "hinder the effective and efficient sharing of information and intelligence." same differences provide for a rich environment in which multiple perspectives are represented within a single organization. Exploiting this diversity is the raison d'être of intelligence centers. Even though it is unlikely that a center ever achieves a perfect interagency process, where resources and capabilities would be fused seamlessly, progress towards this ideal is possible.

The efforts to stir the interagency process at EPIC started slowly and have proved challenging ever since. Evidence of tensions emerged in the media as early as 1975 when the Los Angeles Times reported a "feud" between the DEA and the Customs Services over the amount of marijuana being smuggled from Mexico and the Caribbean to the US through the air. ${ }^{73}$ The same year, a government report found that federal drug law enforcement efforts continued to suffer from "problems of fragmented organization and resulting interagency conflicts" between the DEA, Customs and the FBI. ${ }^{74}$ The intersection of responsibilities for drug law enforcement was not fundamentally altered by the presidential reorganization plan that established the DEA in 1973. Despite some early successes in the form of arrests, interagency conflicts subsisted, including jurisdictional disputes revolving around the distinction between interdiction and investigation, and the different methods of operation used by the three federal agencies at EPIC. To force effective interagency cooperation the General Accounting Office recommended "a clear directive on the part of someone acting on the President's behalf to compel agencies to comply." 75 This advice, that of an outsider organization, remained unheeded. The interagency process continued to pose problems less than a decade later, when another Government Accounting Office report found that, as a result of persisting bureaucratic wrangling, EPIC was "not being fully supported by participating agencies" and this situation impacted negatively on several interdiction projects. ${ }^{76}$

This problem has not completely disappeared, if anything, EPIC's growth and the participation of new agencies has further complicated interagency coordination. The establishment of the Department of Homeland Security in 2002 effectively brought together a host of organizations involved in the Center under a single leadership and 
affected the delicate inter-institutional balance within EPIC. The global war on terrorism also strengthened the role of Department of Defense components working on homeland defense and lead to a greater involvement of military personnel with EPIC. ${ }^{77}$ One of the key issues encountered at this level is the different methods and approaches to intelligence followed by law enforcement professional working in drug interdiction and other military and intelligence professionals working on counterterrorism and homeland defense. ${ }^{78}$ For instance, the intelligence and defense communities tend to use higher classification standards than their law enforcement counterpart and this can complicate the sharing of information. ${ }^{79}$ A 2010 DOJ report found that EPIC was not effectively resolving coordination issues "such as ensuring that priorities are agreed upon so that programs are sustained and that member agencies meet expectations for participation and information sharing. ${ }^{\prime 80}$ The recent adoption of a new charter (in 2015) may improve this situation.

The multiplicity of organizations involved in drug interdiction also complicates coordination between EPIC and outside organizations. In the 1990s, EPIC and other government agencies involved in countering narco-trafficking reportedly remained deeply divided. ${ }^{81}$ More recently, EPIC's coordination with federal and state intelligence organizations across the country, in particular with key intelligence centers, has been found to be inconsistent. ${ }^{82}$ The multiplication of fusion centers in the aftermath of the 9/11 attacks has added a layer of organizations and further complicated inter-institutional coordination. ${ }^{83}$

In addition to problems of coordination, EPIC has faced issues of functional overlap. ${ }^{84}$ In 2004, a top-down review of DEA intelligence included a survey in which 87 percent of the respondents considered that the roles and missions of EPIC and other similar organizations overlapped or were redundant to some degree. The study notes that this is an issue of "perception," yet it also identifies overlaps between EPIC and a variety of local and regional centers, tasks forces and field divisions involved in drug interdiction. ${ }^{85} \mathrm{~A}$ recent DOJ report confirms the trend and remarks that "there is an increased likelihood for duplication of effort. ${ }^{" 86}$ Within El Paso, and at the state and national levels, EPIC is only but one of a host of fusion centers. ${ }^{87}$ 
The plethora of multi-agency centers involved in drug enforcement raises important questions about the efficiency of the government's efforts in this domain. However, the inevitable overlap between these center's missions and activities is not necessarily a waste of resources; decision-makers at various levels of government require tailored products and services on similar issues. The negative effects of these overlaps can also be minimized through careful coordination. Even though EPIC does not have the authority to impose its priorities to other centers and agencies, it can make its voice heard. From this perspective, the various entities involved in drug interdiction and law enforcement along the Southwest border should continue to meet and coordinate their actions at multiple levels through working groups. ${ }^{88}$ At higher levels, decision-makers need periodic surveys of the drug enforcement efforts along the border to keep an eye the need for reorganization.

Beyond governance issues, interagency coordination rests on technical solutions. Agencies collect information in different ways and common systems need to be set up to overcome these differences and communicate effectively. This technical challenge was confronted at EPIC thanks to the development of programs which store, retrieve, correlate intelligence and provide "opportunities for different investigators to "get together" on a case despite geographic distance." 89 A central aspect of the technical solutions provided by EPIC has been the development of a deconfliction mechanism "that notifies the appropriate parties when common links are identified among investigations." This process started informally, with EPIC putting officers in contact when it received a request and knew that other customers had made a similar request. ${ }^{90}$

Today, deconfliciton is computerized and all the queries to the Center are kept in a database that allows EPIC to put requesters in contact with each other. This process prevents overlaps between interdiction, that is to say seizures and arrests, and ongoing investigations. The database can also be used to point to specific directions where more information might be, for example it may point a federal agent towards specific nonfederal databases. At this level, technology clearly enables EPIC to better serve its customers. The 2016 DOJ congressional submission, in which the department requests for further funding to update EPIC's information technology systems, confirms that the Center's leadership is well aware of the continuing importance of this key enabler. 
Considering the human dimension, another enabler highlighted by Walsh, frequent interactions between EPIC employees from various government agencies have ensured cooperation through informal means. Acquaintances working on the same floor or within the same unit often prove useful to break the stovepipes that hinder the sharing and dissemination of information and intelligence products across the US law enforcement and intelligence communities. At the individual level, interagency relations are furthered by regular working meetings and the use of peer review within many units. From this perspective the existence of the Center fosters a culture of cooperation that is beneficial to drug enforcement and broader national security efforts.

While EPIC employees work together, for the most part, they do not receive common, interagency, training. Each participating agency provides its own initial training, and sometimes opportunities for continuing professional development, to its employees. In some cases, an agency providing training for its employees may extend an invitation to members of other agencies working at the Center, but EPIC does not provide its own training. Some employees simply learn on the job the specific tasks they will conduct for the Center. This is the case of those employees working at the watch, who have to be able to make efficient use of the dozens of databases available at EPIC. More controversially, in the time of crisis that followed the 9/11 attacks, administrative assistant and secretary positions were converted into intelligence analysts positions to fill workforce gaps, without providing these clerks with any analytical training. This situation, even though it may have been exceptional, could have been resolved thanks to the provision of analytic training by the Center. Providing systematic and joint training to EPIC employees across all levels could provide EPIC with a further opportunity to adapt its workforce and nurture an interagency culture.

\section{Outcomes and outputs}

EPIC's activities are generally well aligned with the security objectives set by the US government in the domain of drug enforcement. US security strategies emphasize the need to coordinate various government agencies' efforts to combat organized crime and disrupt domestic drug trafficking and production. ${ }^{91}$ The mere existence of a multi- 
jurisdictional intelligence center facilitating access to multiple agencies' resources and capabilities should contribute to this objective. Drug control strategies often determine specific indicators to measure the progress made towards the objectives they set. In the realm of drug interdiction, these indicators typically refer to outputs like the number of organizations disrupted or dismantled, and the amount of drug seizures. Since EPIC's role is not to arrest criminals and seize drugs, but to provide support to those who do so, other indicators are needed. For example, the National Drug Control Strategy refers to an increase in the number of databases an organization gives access to, as an indicator of its contribution towards information sharing. This is problematic since the mere existence of an accessible database does not say anything about its applications and overall usefulness.

The National Drug Control Strategy also uses increases in the timeliness of selected federal datasets, and the number of datasets that establish feedback, to measure improvement in information systems. ${ }^{92}$ EPIC's recent efforts to make the NSS database more reliable, gain and give access to new databases (e.g. those of the High Intensity Drug Trafficking Area network), and ask for feedback on its analytical reports, suggest that the Center is actively trying to fulfil these objectives. However, feedback is not systematically sought, especially when RFI concern information (as opposed to intelligence).

The latest DOJ congressional submission puts a similar emphasis on metrics and details the number of RFI EPIC was able to reply to and the related use of EPIC's federated databases system on a yearly basis. ${ }^{93}$ EPIC's management review system also seems to be, at least partly, based on numbers. Chiefs of unit expect their supervisees to successfully reply to a certain number of RFI every day, week and month. EPIC employees thus fill out spreadsheets in which they report their various activities, track the RFI they have answered and the number of active investigations they have supported. However, relying on quantifiable outputs does not always account for the quality and the amount of work devoted to answer a request. One of the issues at this level is that EPIC's basic reporting system does not differentiate between requests focusing on a specific piece of information, and those that require an in-depth assessment. 
Reporting based on strictly quantitative measures provides for an incomplete review of the Center's performance. Such measures focus on specific outputs to the detriment of less quantifiable outcomes like the enduring sense of community and informal networks that develop when people work together and its impact on EPIC's ability to fuse resources and capabilities. Likewise, quantitative measures are ill-suited to assess the quality and relevance of the Center's services and products. ${ }^{94}$ The recent addition of feedback forms to EPIC's intelligence reports provides an opportunity to assess the Center's performance in a more qualitative way. EPIC's main function is to support drug enforcement efforts, and its customers are ideally placed to assess the Center's ability to inform their decisions.

Occasional reviews of EPIC by external entities have historically provided wellrounded appraisals of the Center's activities. The latest review by the DOJ IG has apparently encouraged EPIC to improve some of its core processes, for example by seeking customer's feedback more systematically. However, the Center's leadership should not wait for such reviews to seek improvements. EPIC's performance needs to be considered systematically and comprehensively, thanks to the use of quantitative as well as qualitative methods. EPIC's efforts to disseminate information to law enforcement officers still lacks a well-established feedback loop that could more consistently inform the center's efforts at the tactical level. The Center also needs to clearly distinguish between information and intelligence when assessing its own performance. While the former is generally disseminated in a timely manner, the time-consuming process through which intelligence is produced at EPIC impedes upon the timeliness of its reports. Overall, more comprehensive assessments of the Center's performance will provide a more solid basis to improve its services and products, and adapt to the needs of its customers and employees.

\section{Conclusion}

The El Paso Intelligence Center underwent a tremendous expansion over the last four decades and this alone is a testimony to its ability to promote its organizational interests. A growing number of agencies have joined and continue to support EPIC, finding a 
common interest in sharing their resources and capabilities. RFI sent to EPIC have generally increased too, which suggests there is a clear demand for EPIC's services and products. EPIC has generated a series of tactical successes in the realm of drug enforcement and even proved its value in counterterrorist efforts, a feat that most DHS fusion centers are at pain to achieve. ${ }^{95}$

The Center provides metrics and emphasizes success stories to demonstrate its contribution to the US government interdiction efforts. However, more comprehensive and systematic review mechanisms have the potential to better inform EPIC's leadership about the Center's performance. Once these foundations are established, leadership will be crucial to ensure the Center continues to prove its relevance amid a growing number of similar organizations in the region and beyond. EPIC has demonstrated an ability to change to improve its processes. This ability to change and, more importantly, the Center's ability to adapt on its own initiative, are essential to its future performance. ${ }^{96}$

\footnotetext{
${ }^{1}$ Todd Masse, Siobhan O’Neil and John Rollins, 'Fusion Centers: Issues and Options for Congress', Congressional Research Service, 6 July 2007; US Senate, Permanent Subcommittee on Investigations, Committee on Homeland Security and Governmental Affairs, Federal Support for and Involvement in State and Local Fusion Centers, 3 October 2012; Jason Barnosky, "Fusion Centers: What's working and what isn't," 17 March 2015, <http://www.brookings.edu/blogs/fixgov/posts/2015/03/17-fusion-centersbarnosky> (accessed 22 July 2015).

${ }^{2}$ Philip Zelikow et al. (eds) The 9/11 Commission Report: final report of the National Commission on terrorist attacks upon the United States (New York: W.W. Norton, 2004), pp.399-423; Calvert Jones, 'Intelligence reform: The logic of information sharing', Intelligence and National Security 22/3 (2007), pp.384-401; Sharon S. Dawes, Anthony M. Cresswell, Theresa A. Pardo, 'From "Need to Know" to "Need to Share": Tangled Problems, Information Boundaries, and the Building of Public Sector Knowledge Networks', Public Administration Review 69/3 (2009), pp.392-402.

${ }^{3}$ White House, Executive Order 13354, 27 August 2004; Zelikow et al., The 9/11 Commission Report, p.403; Government Accountability Office, 'Information Sharing: DHS Is Assessing Fusion Center Capabilities and Results, but Needs to More Accurately Account for Federal Funding Provided to Centers', 4 November 2014, p.6.

${ }^{4}$ Homeland Security Council, National Strategy for Homeland Security, October 2007, p.49; Office of the Director of National Intelligence, National Intelligence Strategy, August 2009, p.14; White House, National Security Strategy of the United States of America, May 2010, p.20; Office of the Director of National Intelligence, National Intelligence Strategy, 2014, pp.12-13; Department of Justice, Fiscal Years 20142018, Strategic Plan, pp.21, 27-28.

${ }^{5}$ US Congress, Intelligence Reform and Terrorism Prevention Act, $108^{\text {th }}$ Congress, $2^{\text {nd }}$ sess., 17 December 2004, Sec. 1016. On the US culture of divisiveness, see: Philip H. Davies, 'Intelligence and the machinery of government: conceptualizing the intelligence community', Public Policy and Administration 25/1 (2010), pp.29- 46; Roger Z. George and Harvey Rishikof, 'The National Security Enterprise: Institutions, Cultures, and Politics', in Roger Z. George and Harvey Rishikof (eds.), The National Security Enterprise (Washington, DC: Georgetown University Press, 2011), pp.5-6.

${ }^{6}$ Department of Justice, Fusion Center Guidelines. Developing and Sharing Information and Intelligence in a New Era, 2008, pp.2, 12; Department of Homeland Security, Fusion Center Guidelines, 2006, p.3; Patrick Walsh, Intelligence and Intelligence Analysis (New York: Routledge, 2011), p.110; Robert W. Taylor and
} 
Amanda L. Russell, 'The failure of police 'fusion' centers and the concept of a national intelligence sharing plan', Police Practice and Research 13/2 (2012), p.185.

${ }^{7}$ Estimates of the total amount of federal dollars spent by the Department of Homeland Security alone on state and local fusion center activities from 2003 to 2011 vary from \$278 million to \$1.4 billion.

Government Accountability Office, 'Information Sharing', p.6; US Senate, Permanent Subcommittee on Investigations, Committee on Homeland Security and Governmental Affairs, Federal Support for and Involvement in State and Local Fusion Centers, p.9.

${ }^{8}$ John P. Sullivan and Robert J. Bunker, 'Multilateral Counter-Insurgency Networks', Low Intensity Conflict \& Law Enforcement 11/2-3 (2002), pp.353-368; John P. Sullivan and James J. Wirtz, 'Terrorism Early Warning and Counterterrorism Intelligence", International Journal of Intelligence and CounterIntelligence 21/1 (2008), pp.13-25; Joseph W. Pfeifer, 'Network Fusion: Information and Intelligence Sharing for a Networked World', Homeland Security Affairs 8/1 (2012), pp.1-19.

${ }^{9}$ For examples of fusion in other contexts, see: Peter Jackson, France and the Nazi Menace: intelligence and policy making, 1933-1939 (New York: Oxford University Press, 2000), pp.41-42; Michael S. Goodman, 'Learning to Walk: The Origins of the UK's Joint Intelligence Committee', International Journal of Intelligence and CounterIntelligence 21/1 (2007), pp.40-56; James J. Wirtz and Jon J. Rosenwasser, 'From Combined Arms to Combined Intelligence: Philosophy, Doctrine and Operations', Intelligence and National Security 25/6 (2010), pp.725-743; Ben Connable, Military Intelligence Fusion for Complex Operations: A New Paradigm (Santa Monica, CA: Rand Corporation, 2012).

${ }^{10}$ On the use of task forces in drug interdiction, see: Edmund F. McGarrell and Kip Schlegel, 'The implementation of federally funded multijurisdictional drug task forces: Organizational structure and interagency relationships', Journal of Criminal Justice 21/3 (1993), pp.231-244; David L. Carter and Jeremy G. Carter, 'The intelligence fusion process for state, local, and tribal law enforcement', Criminal Justice and Behavior 36/12 (2009), pp.1324-6.

${ }^{11}$ The DEA is the federal agency responsible for enforcing the controlled substance laws and regulations of the United States.

${ }^{12}$ Drug Enforcement Administration, 'DEA Museum Lecture Series - An Overview of the El Paso Intelligence Center', 1 December $2011<\mathrm{http}$ //www.deamuseum.org/education/transcripts/EPIC120111.pdf $>$ (accessed 1 July 2015)

${ }^{13}$ Ratcliffe defines crime intelligence as 'the result of the analysis of not only covert information from surveillance, offender interviews and confidential human sources (informants), but also crime patterns and police data sources as well as socio-demographic data and other non-police data.' Jerry Ratcliffe, Intelligence-Led Policing (Cullompton: Willan, 2008), p.7.

${ }^{14}$ Illinois Interview \#3 (with a DHS official) in Erik J. Dillman, 'Federalism \& Homeland Security: A Comparative Study', A Dissertation Presented to the Faculty of the Graduate School of Saint Louis University in Partial Fulfillment of the Requirements for the Degree of Doctor in Philosophy, 2008, p.406. ${ }^{15}$ Office of National Drug Control Policy, National Southwest Border Counternarcotics Strategy, 2013.

${ }^{16}$ Department of Homeland Security, 'Top Story: El Paso Intelligence Center turns raw data into actionable intelligence', 26 June 2012, <http://www.ice.gov/news/releases/top-story-el-paso-intelligence-center-turnsraw-data-actionable-intelligence $>$ (accessed 20 June 2015).

${ }^{17}$ Drug Enforcement Administration, Drug Enforcement Administration: A tradition of Excellence, 2008, p.191; Anthony Placido, 'The El Paso Intelligence Center: Beyond the Border', April 2014,

$<$ http://www.policechiefmagazine.org/magazine/index.cfm?fuseaction=display_arch\&article_id=1201\&iss ue id=62007> (accessed 2 March 2015).

18 Jerome P. Bjelopera and Kristin Finklea, 'Domestic Federal Law Enforcement Coordination: Through the Lens of the Southwest Border', Congressional Research Service, 3 June 2014, p.27; Ratcliffe,

Intelligence-Led Policing, p.189; Walsh, Intelligence and Intelligence Analysis, pp.147-151.

${ }^{19}$ See the framework developed in Walsh, Intelligence and Intelligence Analysis, p.137.

${ }^{20}$ Bjelopera and Finklea, 'Domestic Federal Law Enforcement Coordination', p. 27; Ratcliffe, IntelligenceLed Policing, p.194. 
${ }^{21}$ Richard Nixon, 'Special Message to the Congress on Drug Abuse Prevention and Control', 17 June 1971, $<$ http://www.presidency.ucsb.edu/ws/?pid=3048> (accessed 3 September 2015). On the 'war on drugs', see: Christina J. Johns, Power, Ideology, and the War on Drugs: Nothing Succeeds Like Failure (New York: Praeger, 1992); Steven B. Duke and Albert Gross, America's Longest War: Re-Thinking our Tragic Crusade against Drugs (New York: G. P. Putnam, 1994); Andrew B. Whitford and Jeff Yates, Presidential Rhetoric and the Public Agenda: Constructing the War on Drugs (Baltimore, MD: Johns Hopkins University Press, 2009), pp.34-73.

${ }^{22}$ White House, Reorganization Plan No.2 of 1973; Idem, Executive Order 11727, Drug law enforcement, 6 July 1973.

${ }^{23}$ National Archives and Records Administration (Maryland): Record of the Drug Enforcement Administration, Legislative File, 1969-1979, Box 1 (170-86-0161): Office of Chief Counsel,

'Interrelationship Between the Bureau of Narcotics and Dangerous Drugs and the Bureau of Customs Regarding Narcotics and dangerous Drug Traffic', 17 July 1969, pp.2-4.

${ }^{24}$ Drug Enforcement Administration, Drug Enforcement Administration: A tradition of Excellence, p.15.

${ }^{25}$ Ibid, p. 16.

${ }^{26}$ John B. Brown, III and Joseph B. Long, 'The El Paso Intelligence Center: A National Resources for Local Agencies', Sheriff 52/1 (2000), p.20.

${ }^{27}$ Drug Enforcement Administration, Drug Enforcement Administration: A tradition of Excellence, p.18.

${ }^{28}$ Department of Justice, A Secure Border: An Analysis of Issues Affecting The U.S. Department of Justice, Washington, DC, 4 March 1974, p.89.

${ }^{29}$ Ibid.

${ }^{30}$ Ibid, p.90.

${ }^{31}$ Brown and Long, 'The El Paso Intelligence Center', p.19; Drug Enforcement Administration, Drug Enforcement Administration: A tradition of Excellence, p.18.

${ }^{32}$ General Accounting Office, Federal Drug Enforcement: Strong Guidance Needed, 18 December 1975, p.24; Drug Enforcement Administration, 'DEA Museum Lecture Series', p.4.

${ }_{33}$ Drug Enforcement Administration, 'DEA Museum Lecture Series', pp.8-9; Department of Justice, Office of the Inspector General, Evaluation and Inspections Division, Review of the Drug Enforcement Administration's El Paso Intelligence Center, June 2010, p.i.

${ }^{34}$ Drug Enforcement Administration, Drug Enforcement Administration: A tradition of Excellence, p.31.

${ }^{35}$ Drug Enforcement Administration, 'Intelligence', $<$ http://www.dea.gov/ops/intel.shtml $>$ (accessed 4 March 2015).

${ }^{36}$ Brown and Long, 'The El Paso Intelligence Center', p.20; General Accounting Office, Federal Drug Interdiction Efforts Need strong Central Oversight, 13 June 1983, p.63.

${ }^{37}$ National Archives and Records Administration (Maryland) CIA, CREST: Statement of Drug Enforcement Administration, Department of Justice, before the Select Committee on Intelligence, United State Senate, July 14, 1982, p.5; General Accounting Office, Federal Drug Interdiction Efforts Need strong Central Oversight, p.69; Pete Burton and Bill Childress, 'El Paso Intelligence Center (EPIC) smuggling inter-agency surveillance', Customs Today 26/4 (1991), p.23; Department of Justice, Review of the Drug Enforcement Administration's El Paso Intelligence Center, pp.2-3; Department of Justice, Drug Enforcement Administration, FY2012 Performance Budget Congressional Submission, pp.87, 89.

${ }^{38}$ Michelle Leonhart, Statement before the United States House of Representatives Committee on Appropriations, Subcommittee on Commerce, Justice, Science and Related Agencies, 12 April 2013, p.5. Agencies officially represented at EPIC currently include: The DEA, Department of General Services, Customs and Border Patrol, Immigration and Custom Enforcement, the Coast Guard, the FBI, the Bureau of Alcohol, Tobacco, Firearms and explosives, the Marshall service, the Department of Transportation, the Internal Revenue Service, the Department of Interior, the National Geospatial-Intelligence Agency, the Department of Defense, Joint Task Force-North, the Joint Interagency Task Force-South, Texas Department of Public Safety, Texas Air National Guard, National Guard Counter Narcotics Bureau, the Department of State, the Bureau of Indian Affairs, the Union Pacific Railroad Police, the Kansas City Southern Railroad Police, the El Paso Police Department, and the El Paso County Sherriff's Office. The Central Intelligence Agency, the Defense Intelligence Agency and the National Security Agency are also represented at the Center. See: Government Accounting Office, Drug Control - An Overview of U.S. Counterdrug Intelligence Activities, NSIAD-98-142, June 1998, Appendix I: 2.7.

${ }^{39}$ Memoranda of understanding have no force of law and may be dormant in practice. 
${ }^{40}$ Department of Justice, Review of the Drug Enforcement Administration's El Paso Intelligence Center, pp.i, 4, 9.

${ }^{41}$ General Accounting Office, Federal Drug Interdiction Efforts Need strong Central Oversight, p.65.

42 Drug enforcement Administration, 'DEA Museum Lecture Series', p.17.

${ }^{43}$ Department of Homeland Security, 2014 National Network of Fusion Centers, Final Report, January 2015, p.41.

${ }^{44}$ Department of Justice, FY 2012 Performance Budget Congressional Submission, p.88; Drug

Enforcement Administration, FY 2016 Performance Budget Congressional Submission, p.100.

${ }^{45}$ Santiago Ballina, 'The crime-terror continuum revisited: a model for the study of hybrid criminal organisations', Journal of Policing, Intelligence and Counter Terrorism 6/2 (2011), pp.121-136.

${ }^{46}$ Drug Enforcement Administration, DEA Intelligence Program Top-Down Review, pp.48, 50.

${ }^{47}$ Masse, O’Neil and Rollins, 'Fusion Centers: Issues and Options for Congress', p.7; Editor, 'Hezbollah uses Mexican drug routes into U.S.', Washington Times, 27 March 2009; Louise I. Shelley and Sharon A. Melzer, 'The nexus of organized crime and terrorism: Two case-studies in cigarette smuggling', International Journal of Comparative and applied Criminal Justice 32/1 (2008), pp.43-63; Torin Monahan and Neal A. Palmer, 'The emerging politics of DHS fusion centers', Security Dialogue 40/6 (2009), p.621.

${ }^{48}$ Drug Enforcement Administration, DEA Intelligence Program Top-Down Review, pp.10, 26.

${ }^{49}$ Department of Homeland Security, 'Top Story: El Paso Intelligence Center'.

${ }^{50}$ The term National Security Enterprise is used to describe the multiplicity of actors involved in US national security, including the three branches of government and the private sector. See George and

Rishikof, 'The National Security Enterprise: Institutions, Cultures, and Politics', p.3.

${ }^{51}$ Drug Enforcement Administration, 'Intelligence'.

52 Placido, 'The El Paso Intelligence Center: Beyond the Border'; Department of Justice, Review of the Drug Enforcement Administration's El Paso Intelligence Center, p.11; Drug Enforcement Administration, 'DEA Museum Lecture Series', p.25.

${ }^{53}$ Office of National Drug Control Policy, National Southwest Border Counternarcotics Strategy, 2013, pp.7, 11; idem, National Drug Control Strategy, 2014, p.i.

${ }_{54}^{54}$ Drug Enforcement Administration, 'DEA Museum Lecture Series', p.21.

${ }^{55}$ Department of Justice, Department of Justice, Drug Enforcement Administration FY 2016 Performance Budget Congressional Submission, p.100.

${ }^{56}$ Department of Justice, Drug Enforcement Administration, FY2014 Performance Budget Congressional Submission, p.61.

${ }^{57}$ Brown and Long, 'The El Paso Intelligence Center', p.19.

${ }^{58}$ Office of National Drug Control Policy, National Southwest Border Counternarcotics Strategy, 2013, p. 12 .

${ }^{59}$ Donald A. Schramek, Response Submitted to GAO on their Draft Report Entitled 'Strong Central Management and a More Definite Strategy Needed to Improve Federal Drug Interdiction Efforts', 3 February 1983, p.105; Drug Enforcement Administration, Drug Enforcement Administration: A tradition of Excellence, p.193; General Accounting Office, Federal Drug Interdiction Efforts Need strong Central Oversight, p.115.

${ }^{60}$ Data are facts that are usually compiled into databases. Information is produced when databases are queried to answer specific questions.

${ }^{61}$ Department of Homeland Security, 'Top Story: El Paso Intelligence Center'.

${ }^{62}$ Department of Justice, FY2016 Performance Budget Congressional Submission, p. 100.

${ }^{63}$ Department of Justice, Review of the Drug Enforcement Administration's El Paso Intelligence Center, p.11.

${ }^{64}$ Jeff Stein, 'El Paso intel center error causes couple's arrest at gunpoint', Washington Post, 7 September 2010.

${ }^{65}$ Drug Enforcement Administration, 'DEA Museum Lecture Series', p.10.

${ }^{66}$ Department of Justice, Review of the Drug Enforcement Administration's El Paso Intelligence Center, p.viii; Department of Justice, Drug Enforcement Administration FY 2016 Performance Budget

Congressional Submission, p.14; Government Accounting Office, Drug Control, Appendix I:2.2.

${ }^{67}$ Department of Justice, Review of the Drug Enforcement Administration's El Paso Intelligence Center, p.viii.

${ }^{68}$ Ibid, p.iii. 
${ }^{69}$ Ibid, pp.iii-iv; General Accounting Office, Federal Drug Interdiction Efforts Need strong Central Oversight, pp.57-58, 64.

${ }^{70}$ Department of Justice, Review of the Drug Enforcement Administration's El Paso Intelligence Center, pp.ii-viii, 49-50.

${ }_{71}^{71}$ Walsh, Intelligence and Intelligence Analysis, p.149.

${ }^{72}$ Taylor and Russell, 'The failure of police 'fusion' centers and the concept of a national intelligence sharing plan', p.184; Carter and Carter, 'The intelligence fusion process for state, local, and tribal law enforcement', p.1334.

${ }^{73}$ Editor, 'Drug Smuggling Story Stirs Feud', Los Angeles Times, 7 June 1975, A22.

${ }^{74}$ General Accounting Office, Federal Drug Enforcement, p.25; US Senate, Committee on the Judiciary, Hearings before the Subcommittee to Investigate Juvenile Delinquency, United States Efforts to Halt Heroin Importation: Eradication and Enforcement in Mexico Southwest Broder Control, 10 February and 19 April 1978, p.308.

${ }^{75}$ Ibid, pp.i-ii, 23, 31

${ }^{76}$ General Accounting Office, Federal Drug Interdiction Efforts Need strong Central Oversight, pp.57, 62 $63,66$.

${ }^{77}$ Department of Justice, DEA Intelligence Program Top-Down Review, p.8; Idem, Drug Enforcement Administration, FY 2015 Performance Budget Congressional Submission, p.66.

${ }^{78}$ Drug Enforcement Administration, DEA Intelligence Program Top-Down Review, p.49.

${ }^{79}$ See: Department of Justice, Review of the Drug Enforcement Administration's El Paso Intelligence Center, p.vi.

${ }^{80}$ Department of Justice, Review of the Drug Enforcement Administration's El Paso Intelligence Center, pp.iv-v, 44.

${ }^{81}$ Michael Isikoff, 'Justice Reveals Plans for Drug Data Center; Facility Designed to Fill Intelligence 'Gap', Washington Post, 8 June 1990, A21; Molly Moore, John Ward Anderson, 'U.S.-Mexican Drug Collaboration Fails When Lives Are on the Line', Washington Post, 5 November 1997, A1.

${ }^{82}$ Department of Justice, Review of the Drug Enforcement Administration's El Paso Intelligence Center, pp.ii-viii, 49-50.

${ }^{83}$ Taylor and Russell, 'Failure of Police Fusion Centers and the Concept of National Intelligence Sharing Plan', pp.194-195.

${ }^{84}$ General Accounting Office, Federal Drug Interdiction Efforts Need strong Central Oversight, p.67; Isikoff, 'Justice Reveals Plans For Drug Data Center', A21; Idem, 'Drug Center Arrives in Pork Barrel', Washington Post, 29 October 1990, A13.

${ }^{85}$ Department of Justice, DEA Intelligence Program Top-Down Review: a partnership to build a premier intelligence program, 2004, pp.45-7.

${ }^{86}$ Department of Justice, Review of the Drug Enforcement Administration's El Paso Intelligence Center, pp.vii, 30-31; US Senate, Federal Support for and Involvement in State and Local Fusion Centers, p.11.

${ }^{87}$ Washington Office on Latin America, 'An Uneasy Coexistence: Security and Migration Along the El Paso-Ciudad Juarez Border’, 20 December 2011, $<$ http://www.wola.org/commentary/an_uneasy_coexistence> (accessed 15 February 2015); Sylvia Longmire, 'Texas Opening New Intelligence Center To Combat Border Crime', $<$ http://www.breitbart.com/texas/2015/06/14/texas-opening-new-intelligence-center-to-battle-bordercrime/> (accessed 31 August 2015).

${ }^{88}$ Office of National Drug Control Policy, National Southwest Border Counternarcotic Strategy, p.13.

${ }^{89}$ General Accounting Office, Federal Drug Interdiction Efforts Need strong Central Oversight, p.115.

${ }^{90}$ Drug Enforcement Administration, 'DEA Museum Lecture Series', pp.25-6.

${ }^{91}$ White House, National Security Strategy, February 2015, p.10; Office of the Director of National Intelligence, The National Intelligence Strategy of the United States of America, 2014, p.8; Office of National Drug Control Policy, National Drug Control Strategy, 2014, pp.i, 36-38.

${ }^{92}$ Office of National Drug Control Policy, National Drug Control Strategy, Performance Reporting System Report, 2014, pp.7, 21, 30.

${ }_{93}$ Department of Justice, Drug Enforcement Administration FY 2016 Performance Budget Congressional Submission, p.100; Drug Enforcement Administration, 'DEA Museum Lecture Series', p.16.

${ }_{95}^{94}$ Bjelopera and Finklea, 'Domestic Federal Law Enforcement Coordination', p.29.

${ }^{95}$ US Senate, Federal Support for and Involvement in State and Local Fusion Centers, pp.1-4. 
${ }^{96}$ On the difference between change and adaptation: Amy Zegart, 'September 11 and the Adaptation Failure of U.S. Intelligence Agencies', International Security 29/4 (2005), p.82. 